\title{
Dioxins and PCBs in Meat - Still a Matter of Concern?
}

\author{
Markus Zennegg*
}

\begin{abstract}
Polychlorinated dibenzodioxins (PCDDs) and polychlorinated dibenzofurans (PCDFs) summarized as dioxins, as well as polychlorinated biphenyls (PCBs) are persistent, bio-accumulative and toxic environmental contaminants. Over $95 \%$ of human exposure to these problematic chemicals occurs via the ingestion of fatty rich food like meat and meat products, fatty fish, as well as milk and dairy products. Several major food and feed contamination incidents in Europe during the years 1997 and 2010 revealed the necessity of establishing food and feed monitoring programs for dioxins and PCBs. Various monitoring programs carried out by the Federal Office of Public Health (FOPH) and the Federal Food Safety and Veterinary Office (FSVO), suggest that cattle from extensive farming (suckler cow husbandry) exhibited higher levels of dioxin-like PCBs (dl-PCBs) and exceeded with higher frequency the permitted maximum levels $(\mathrm{ML})$ when compared to conventional raised cattle. The reasons for the higher levels are possibly due to higher levels of PCBs in green fodder (pasture, silage, and hay) when compared to the concentrated feed used in conventional farming. Additionally, an increased uptake of soil, which is known to be a risk matrix for the uptake of dioxins and PCBs in grazing animals, leads to elevated contaminant levels in the suckler cows and hence their calves. Furthermore, PCB point sources present on a farm from older building and construction materials (e.g. PCB-containing wall paints) might result in very high contamination of the animals and the meat produced from them.
\end{abstract}

Keywords: Dioxins · Extensive farming · Food contamination · Polychlorinated biphenyls

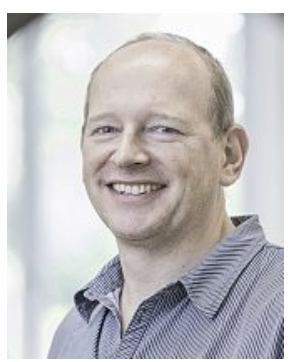

Markus Zennegg

is an analytical chemist and ecotoxicologist working since 1992 for the Swiss Federal Laboratories for Materials Science and Technology (Empa)in Dübendorf. $\mathrm{He}$ is a higher research associate and team leader 'Organic Analytics' in the Laboratory for Advanced Analytical Technologies. His main field of work is focused on gas chromatography high resolution mass spectrometry and the quantitative determination of persistent organic pollutants (POPs) like polyhalogenated dioxins, PCBs, brominated flame retardants etc. in a wide variety of environmental matrices and compartments. He serves as project leader and project partner for different Federal Offices and Cantonal Authorities. Additionally, he is guest lecturer for environmental chemistry and environmental

${ }^{*}$ Correspondence: M. Zennegg

Empa, Swiss Federal Laboratories for Materials Science and Technology

Laboratory for Advanced Analytical Technologies Überlandstrasse 129, CH-8600 Dübendorf

E-mail: markus.zennegg@empa.ch risk assessment at the University of Applied Sciences Zürich (ZHAW) and University of Applied Sciences Northwestern Switzerland in Basel (FHNW). One of his professional highlights was the analytical investigation and follow-up examination in the case of the heavily dioxin-poisoned former Ukrainian president Victor Yushchenko and the discovery of the main dioxin excretion pathway and metabolism.

\section{Introduction}

Since the Seveso accident in Italy in 1976 where several $\mathrm{kg}$ of 2,3,7,8-tetrachlorodibenzodioxin (2,3,7,8-TCDD) were accidentally released into the atmosphere at the ICMESA chemical factory, the term dioxin has become closely related to pictures of young children horribly disfigured by chloracne, one of the acute effects of dioxin intoxication. ${ }^{[1,2]}$ Very likely we can also remember the headlines and pictures in the news of the former Ukrainian President Victor Yushchenko who was heavily dioxin-poisoned and who suffered the same terrible skin disfiguration which was caused by the involuntarily uptake of a tiny amount of 1-2 milligrams of highly pure 2,3,7,8-TCDD. ${ }^{[3,4]}$ Such dramatic cases of acute intoxications caused by the most toxic dioxin led to the frequent appearance of the term dioxin in the popular press as being one of the most toxic man-made chemicals ever. However, the term dioxin includes much more than just one single compound; it represents a whole class of polychlorinated aromatic compounds which are briefly described herein. Polychlorinated dibenzodioxins (PCDDs; 75 congeners), polychlorinated dibenzofurans (PCDFs; 135 congeners) and polychlorinated biphenyls (PCBs; 209 congeners) are persistent, bio-accumulative and toxic environmental contaminants (PBT). Some of the PCBs show a similar toxicity to dioxins and are therefore called dioxin-like PCBs (dl-PCBs). The high toxicity and bio-accumulation potential of PCDD/Fs and PCBs as well as their ubiquitous environmental presence turned these persistent organic pollutants (POPs) into probably one of the most widely studied environmental contaminants ever. As a consequence of their persistence in the environment, $\mathrm{PCDD} / \mathrm{Fs}$ and $\mathrm{PCBs}$ belong to the 28 chemicals and substance classes regulated and listed under the Stockholm Convention, which entered into force in 2004. [5,6] PCDDs and PCDFs are unwanted by-products of combustion processes and some synthetic chemicals. To this very day, they can still be found as trace contaminants in a variety of halogenated pesticides. ${ }^{[7]} \mathrm{On}$ the other hand, PCBs were produced and widely used as industrial chemicals since 1929 with a broad area of application such as plasticisers in anti-corrosion coatings and joint sealants, hydraulic fluids, and insulating fluids for transformers and capacitors. The total amount of PCBs produced 
up until the last factory ceased production in 1993 is estimated to be at least 1.32 million tons, of which approximately $97 \%$ were used in the Northern Hemisphere. ${ }^{[8]}$ Switzerland imported approximately 8,000 tons of PCBs and exported roughly 5,000 tons. In 1972, Switzerland banned the application of PCBs in open systems and since 1986 production, import, and use of PCBs are completely banned in Switzerland. Nevertheless, several hundred tons of PCBs are still present from older applications such as joint sealants, anti-corrosion coatings, industrially contaminated locations, and landfill sites. ${ }^{[9-12]}$ From these and other diffuse reservoirs, PCBs are released into the environment by different pathways and are deposited, for example, via the atmosphere onto soil and plants. ${ }^{[13]}$ The latter form the basis of feedstuff for various farm animals. By the ingestion of plant material and soil particles, PCDD/Fs and PCBs bio-accumulate in the animals (e.g. cattle or sheep) and finally end up in meat or dairy products at the food market and on our table. Due to the ban of PCBs and the continuous elimination of PCB-containing electrical equipment, as well as ongoing improvement of wastewater treatment, incineration and recycling processes, PCB and dioxin levels in the Swiss environment have continuously decreased. ${ }^{[14-18]}$ Nevertheless, during the last two decades almost every year has seen the popular press informing the public about major accidental contamination of food and feed by dioxins and PCBs.[19,20] Such problematic food and feed contaminations are not something new, but as we observe from history, something that appears regularly. ${ }^{[21]}$ In view of this, we can answer the question posed in the title with a yes; dioxins and PCBs in meat and other fat-rich food are still a matter of concern. Although it might not only be a health problem for the consumer, it predominantly leads to a depreciation of the product in the marketplace, with possible bans on marketing and an ensuing huge financial loss being incurred. In the case of small primary producers (e.g. farmers), such imposed bans on marketing might even endanger their existence.

\section{Exposure to Dioxins and РСВ}

Similar positive trends to those mentioned above could additionally be observed in human breast milk samples, which represent a very good indicator for the environmental exposure to highly lipophilic compounds like dioxins and PCBs. During 2000-2010, a decrease of approximately $55 \%$ expressed as toxicity equivalent (TEQ) in the case of the PCDD/ Fs and of approximately $40 \%$ in the case of the dioxin-like PCBs (dl-PCBs) was observable in a global human breast milk survey carried out by the World Health Organization (WHO). ${ }^{[22,23]}$ Despite these positive trends regarding dioxin and $\mathrm{PCB}$ levels in the environment, over $95 \%$ of human exposure to these persistent organic pollutants results from the intake of fatty rich food. In Fig. 1, the contribution of the main food categories to the daily intake (DI) of PCDD/Fs and PCBs expressed as WHO toxicity equivalent (WHO-TEQ) is represented. As can be clearly seen, fatty rich food categories like dairy products and meats contribute $44 \%$ and $25 \%$, respectively, to the daily intake, followed by fish and cheese with contributions of $10 \%$ each, and plants (8\%) and eggs $(3 \%)$ contributing a minor percentage. ${ }^{24]}$ With a contribution of $25 \%$ to the daily WHOTEQ intake, meat and meat products must be considered as being a major contributor alongside dairy products. a tolerable weekly intake (TWI) of $14 \mathrm{pg}$ $\mathrm{TEQ} / \mathrm{kg}$ bw (kilogram of bodyweight) per week, with the US Environmental Protection Agency (US EPA) giving an oral reference dose (RfD) of $0.7 \mathrm{pg}$ TEQ/kg bw per day. ${ }^{[25,26]}$ The TWI recommended by the SCF would correspond to a TDI of 2 pg TEQ/kg bw per day. With an estimated daily intake of $1.75 \mathrm{pg}$ WHO-TEQ ${ }_{2005} / \mathrm{kg}$ bw, the average Swiss population is close to the TDI of $2 \mathrm{pg}$ TEQ $/ \mathrm{kg}$ bw and clearly above the RfD of $0.7 \mathrm{pg} T E Q / \mathrm{kg}$ bw recommended by the US EPA. Similar average daily intakes of $2.11 \mathrm{pg} T E Q / \mathrm{kg}$ bw were recently published in a German study, corresponding to $105 \%$ of the TDI. For high-end consumers, a daily average intake of $3.56 \mathrm{pg} \mathrm{TEQ} / \mathrm{kg}$ bw was reported, corresponding to $178 \%$ of the recommended TDI by the SCF. ${ }^{[27]}$ An exposure assessment published by the European Food Safety Authority (EFSA) concluded that depending on the age group, between

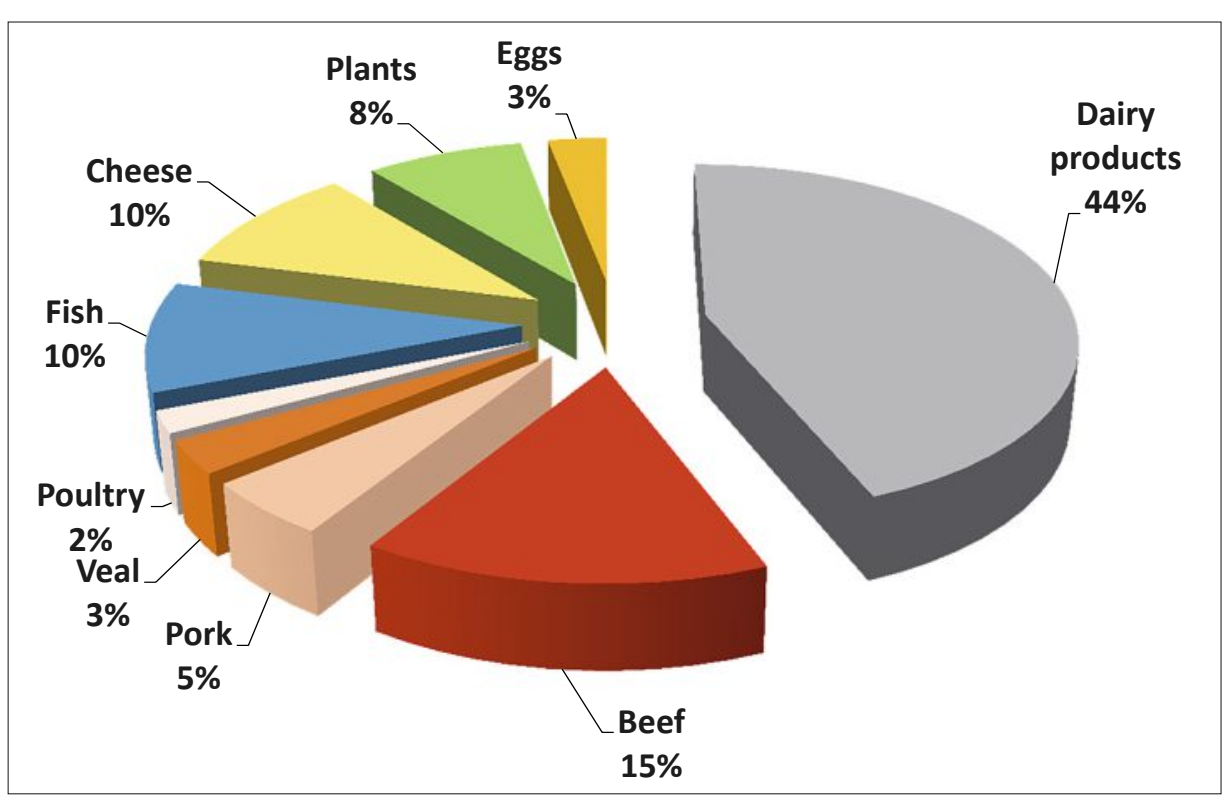

Fig. 1. Contribution of major food categories to the $W H O-T_{E Q} Q_{2005}$ daily intake of the average Swiss population of $1.75 \mathrm{pg} T E Q / \mathrm{kg}$ bw per day.

Considering these facts, several monitoring programs examining the levels of PCDD/Fs and PCBs in different food and feed from the Swiss market were carried out by the Federal Office of Public Health (FOPH) and more recently by the Federal Food Safety and Veterinary Office (FSVO), which was created in 2014 through a fusion of the food safety unit of the FOPH and the Federal Veterinary Office (FVO). [24] Today the average daily intake of dioxins and dioxin-like PCBs in Switzerland via the ingestion of food is estimated to be $1.75 \mathrm{pg}$ WHO-TEQ ${ }_{2005} / \mathrm{g}$ lw (gram of lipid weight). ${ }^{[24]}$ To protect humans from negative long-term effects by the intake of dioxins and dioxin-like PCBs, the Scientific Committee on Food (SCF) recommended
1 and $53 \%$ of the population are exposed above the TWI of $14 \mathrm{pg}$ TEQ/kg bw. ${ }^{[28]}$ In the light of this data, further measures have to be taken to reduce human exposure to dioxins and PCBs. Therefore, monitoring programs are a valuable instrument to highlight those feed and food categories $\mathrm{w}$ TEQhich are critical regarding their contamination levels with dioxins and PCBs

\section{Major Contamination Incidents and Results from Food Monitoring Programs}

Several major and severe contamination incidents of food and feed with dioxins and PCBs occurred in Europe and oth- 
Table 1. Major incidents leading to high contamination of feed and food with PCDD/Fs and PCBs according to Malisch and Kotz, ${ }^{[19]}$ and Hoogenboom et al. ${ }^{[20]}$

\begin{tabular}{|c|c|c|c|}
\hline Country & Year & Product and source of contamination & Discovered by \\
\hline US & 1957 & Feed fat, cow hides, chlorophenols & Effects, authorities \\
\hline Japan & 1968 & Rice oil, contaminated with PCB-oil & Effects \\
\hline Taiwan & 1979 & Rice oil, contaminated with PCB-oil & Effects \\
\hline Netherlands & 1989 & $\begin{array}{l}\text { Grass and milk, higher PCDD/F levels in animals grazing close to municipal } \\
\text { waste incinerators }(M W I) \text { and metal reclamation plant }\end{array}$ & Authorities \\
\hline US & 1996 & Feed, chickens, cat fish, Ball clay, PCDD/F source unknown & Authorities \\
\hline Germany & 1997 & Brazilian citrus pulp, lime $(\mathrm{CaO}), P V C$, industrial land fill site & Authorities \\
\hline Belgium & 1999 & Feed fat, $P C B$-oil & Effects, private \\
\hline Austria & 1999 & Kaolinic clay, $P C D D / F$ source unknown & Authorities \\
\hline $\begin{array}{l}\text { Germany, } \\
\text { Spain }\end{array}$ & 2000 & $\begin{array}{l}\text { Animal feed, choline chloride, saw dust contaminated with pentachlorophe- } \\
\text { nol }(P C P)\end{array}$ & Authorities \\
\hline Italy & $2001-2004$ & Mozzarella, waste incineration & Authorities \\
\hline Germany & 2003 & Animal feed, dried bakery waste, waste wood used for drying & Private \\
\hline Italy & 2004 & Eggs, meat, wood shavings, pentachlorophenol (PCP) & Authorities \\
\hline Netherlands & 2004 & Animal feed, milk, potato peels contaminated by kaolinic clay & Private \\
\hline Netherlands & 2006 & Feed fat, pig feed, gelatine, contaminated $\mathrm{HCl}$ & Authorities \\
\hline $\begin{array}{l}\text { India } \\
\text { Switzerland }\end{array}$ & 2007 & $\begin{array}{l}\text { Guar gum, thickener for food industry (dairy products), pentachlorophenol } \\
(P C P)\end{array}$ & Private \\
\hline Italy & 2008 & Mozzarella, illegal waste burning & Authorities \\
\hline $\begin{array}{l}\text { Chile } \\
\text { Korea }\end{array}$ & 2008 & Pork feed, contaminated zinc oxide & Authorities \\
\hline Ireland & 2008 & Pork and beef, dried bakery waste, $P C B$ s in fuel & Private, authorities \\
\hline Netherlands & 2008 & Feed additive, choline chloride, brominated additives, brominated dioxins & Authorities \\
\hline $\begin{array}{l}\text { Netherlands } \\
\text { Germany }\end{array}$ & 2010 & Organic corn, eggs, source unknown & Private, authorities \\
\hline Germany & $2010 / 11$ & Animal feed, eggs, meat, industrial fatty acids, chlorophenols & Private \\
\hline
\end{tabular}

er countries during the late 1990s and in 2011. Table 1 summarizes these incidents and presents the source of contamination, as well as those who discovered the contamination. The data presented therein is explained in detail and summarized in the publications of Malisch and Kotz, ${ }^{[19]}$ and Hoogenboom et al. ${ }^{[20]}$

Such major contamination incidents have caused the loss of hundreds of millions of Euros in several of the listed cases and highlight the necessity of regularly monitoring our feed, food, food products and ingredients for the presence of dioxins and PCBs. Additionally, these incidents revealed that many different sources can be responsible for the contamination of food and feed with these types of contaminants. Since the beginning of these major contamination incidents, the Federal Office of Public Health (FOPH) has been aware of the problem and has regularly monitored different food categories for their levels of PCDD/Fs and PCBs. The reports which present the findings are publicly available online. [24]

Three monitoring programs with a focus upon meat samples carried out in the years 2003, 2006 and 2008 revealed that cattle meat from extensive farming (suckler cow husbandry), more frequently exceeded the maximum levels (ML; see Table 2) permitted for the sum of the WHO toxicity equivalent (TEQ) of the PCDD/Fs and dl-PCBs valid for the European Union and Switzerland when compared to veal and beef from conventional farming. [24,29-33]

Triggered by the above-mentioned observations, the dioxin and PCB monitoring program in 2012 was focused on cattle meat from extensive farming. 60 meat samples from 53 farms were examined for their PCDD/F and PCB levels. Meat from three farms exceeded the ML, which corresponds to $5.7 \%$ of the samples tested. Although this percentage of non-compliant samples does not seem to be extraordinarily high and almost $95 \%$ of the tested meat was below the ML, approximately 50\% of the analysed meat samples were above the action level (AL) of 1.75 pg WHO$\mathrm{TEQ}_{2005} / \mathrm{g}$ lw. According to the European Union Commission Recommendation 2013/711/EU, an exceedance of the AL would highlight cases where it is appropriate to search for and identify sources of contamination and to take measures for its reduction or elimination. ${ }^{[31]} \mathrm{A}$ similar situation with cattle from extensive farming also exists in Germany. According to a study carried out for the German Environment Agency (Umweltbundesamt - UBA), 25\% of the meat samples originating from ex- 
Table 2. Maximum levels (ML) and action levels $(\mathrm{AL})$ for some food and feed categories, according to Swiss and EU legislation.

\begin{tabular}{|c|c|c|c|c|c|}
\hline \multirow[t]{2}{*}{ Food category } & $\begin{array}{c}\text { ML WHO-TEQ } \\
\text { PCDD/F }\end{array}$ & $\begin{array}{c}\text { ML WHO-TEQ } \\
\text { PCDD/F + dl- } \\
\text { PCB }\end{array}$ & $\begin{array}{c}\text { AL WHO-TEQ } \\
\text { PCDD/F }\end{array}$ & $\begin{array}{l}\text { AL WHO-TEQ } \\
\text { dl-PCB }\end{array}$ & $\begin{array}{c}\text { ML ndl-PCB } \\
\text { (Sum PCB 28, } \\
\text { 52, 101, 138, } \\
153,180)\end{array}$ \\
\hline & $\mathrm{pg} / \mathrm{g}$ fat & $\mathrm{pg} / \mathrm{g}$ fat & $\mathrm{pg} / \mathrm{g}$ fat & $\mathrm{pg} / \mathrm{g}$ fat & ng/g fat \\
\hline $\begin{array}{l}\text { Bovine animals and } \\
\text { sheep }\end{array}$ & 2.5 & 4.0 & 1.75 & 1.75 & 40 \\
\hline Poultry & 1.75 & 3.0 & 1.25 & 0.75 & 40 \\
\hline Pigs & 1.0 & 1.25 & 0.75 & 0.50 & 40 \\
\hline \multirow{2}{*}{$\begin{array}{l}\text { Raw milk and dairy } \\
\text { products }\end{array}$} & 2.5 & 5.5 & 1.75 & 2.0 & 40 \\
\hline & pg/g wet weight & pg/g wet weight & pg/g wet weight & pg/g wet weight & ng/g wet weight \\
\hline $\begin{array}{l}\text { Liver of bovine animals, } \\
\text { poultry and pigs }\end{array}$ & 0.30 & 0.50 & - & - & 3.0 \\
\hline Liver of sheep & 1.25 & 2.0 & - & - & 3.0 \\
\hline \multirow[t]{2}{*}{$\begin{array}{l}\text { Products intended for } \\
\text { animal feed }\end{array}$} & $\begin{array}{c}\text { ML WHO-TEQ } \\
\text { PCDD/F }\end{array}$ & $\begin{array}{c}\text { ML WHO-TEQ } \\
\text { PCDD/F + dl- } \\
\text { PCB }\end{array}$ & $\begin{array}{l}\text { AL WHO-TEQ } \\
\text { PCDD/F }\end{array}$ & $\begin{array}{l}\text { AL WHO-TEQ } \\
\text { dl-PCB }\end{array}$ & $\begin{array}{c}\text { ML ndl-PCB } \\
\text { (Sum PCB 28, } \\
52,101,138 \\
153,180)\end{array}$ \\
\hline & ng/kg & $\mathrm{ng} / \mathrm{kg}$ & ng/kg & $\mathrm{ng} / \mathrm{kg}$ & $\mu \mathrm{g} / \mathrm{kg}$ \\
\hline Feed of plant origin & 0.75 & 1.25 & 0.50 & 0.35 & 10 \\
\hline $\begin{array}{l}\text { Animal fat including } \\
\text { milk }\end{array}$ & 1.50 & 2.0 & 0.75 & 0.75 & 10 \\
\hline
\end{tabular}

$\mathrm{ML}=$ Maximum Levels; $\mathrm{AL}=$ Action Levels; ML and AL according to: Kontaminantenverordnung (VHK) Stand 1. Mai 2017 Anhang 5; Commission Regulation (EU) No 1259/2011; Commission Regulation (EU) No 277/2012; Commission Regulation (EU) No 1067/2013; Commission Recommendation (EU) 2013/711 EU.

tensive farming (suckler cow husbandry) were above the permitted ML for PCDD/ Fs and dl-PCBs, with $14 \%$ still exceeding the ML when the analytical measurement uncertainty was taken into account.[34,35] Therefore, it may likely be assumed that in Switzerland too, approximately $10-15 \%$ of the meat originating from extensive farming could exceed the ML set for PCDD/Fs and dl-PCBs, since the spectrum of PCB use is comparable to our neighbouring country.

From the above-mentioned three farms (named herein as farms A, B and $\mathrm{C})$, with the non-compliant meat samples, total $\mathrm{PCDD} / \mathrm{F}$ and dl-PCB WHO$\mathrm{TEQ}_{2005}$ levels in veal from farms $\mathrm{A}$ and B slightly exceeded the ML with 7.3 and $5.3 \mathrm{pg} \mathrm{WHO}^{-\mathrm{TEQ}_{2005}} / \mathrm{g}$ lw respectively. Otherwise the levels for the sum of the non-dioxin-like PCBs (ndl-PCBs; $\Sigma$ of PCB 28, 52, 101, 138, 153 and 180) were below the ML of $40 \mathrm{ng} / \mathrm{g}$ lw applicable for these types of PCBs. In contrast, veal from farm $C$ revealed high levels of $19 \mathrm{pg}$ WHO-TEQ ${ }_{2005} / \mathrm{g}$ lw, thus exceeding the ML of $4 \mathrm{pg}$ WHO-TEQ ${ }_{2005} / \mathrm{g}$ lw by almost a factor of five. Additionally, the sum of the non-dioxin-like PCBs (ndl-PCBs) was very high at $480 \mathrm{ng} / \mathrm{g}$ and twelve times above the ML of $40 \mathrm{ng} / \mathrm{g}$ lw. Such a clear exceedance of the MLs calculated as WHO-TEQ 2005 and the sum of the ndl-PCBs is generally indicative of a single PCB point source and not of a diffuse contamination with PCB. Based on these results, the three producers of the veal concerned were traced back and additional samples were taken from the farms and analysed to make sure that the contaminated samples were representative for the whole herd and not merely outliers. The elevated levels were indeed confirmed in two out of the three farms (farms $A$ and $C$ ). In all samples, the dl-PCBs contributed with $83 \%$ to $97 \%$ to the total $\mathrm{WHO}-\mathrm{TEQ}_{2005}$. This high contribution is not surprising as dlPCBs generally contribute approximately $70-90 \%$ to the total WHO-TEQ ${ }_{2005}$ in fatty rich food items. The Cantonal authorities responsible banned the direct marketing of meat from farm A and imposed a total ban on marketing in the case of the highly contaminated meat from farm C. Further investigations were initiated to investigate possible reasons for the slightly elevated
PCB levels in cattle from farm A and the high contamination in the case of farm $\mathrm{C}$.

Analyses of approximately 20 feed and material samples taken in the stable of farm $\mathrm{C}$ eventually revealed two wall coatings with high totals of PCB contents at $16 \%$ and $3 \%$ respectively as the primary source of contamination. According to the farmer, these paints were applied after construction of the stable more than 45 years ago. Confirmation of this primary source was also based on the perfect matching between the PCB congener pattern of the meat samples, the suckler cow's milk and the wall paints as displayed in Fig. 2.[36]

The valid question then arose as to whether this farm is the only one of over 40,000 cattle farms in Switzerland with wall paints containing high amounts of PCBs. Future investigations in this direction might be able to answer this question. To assure the future survival of farm $C$, the stable had to undergo complete remedial work under strict safety measures to protect both humans and the environment. The costs for the remedial work on the stable (CHF 70,000.-), including the farmer's financial losses, the expenditures for in- 


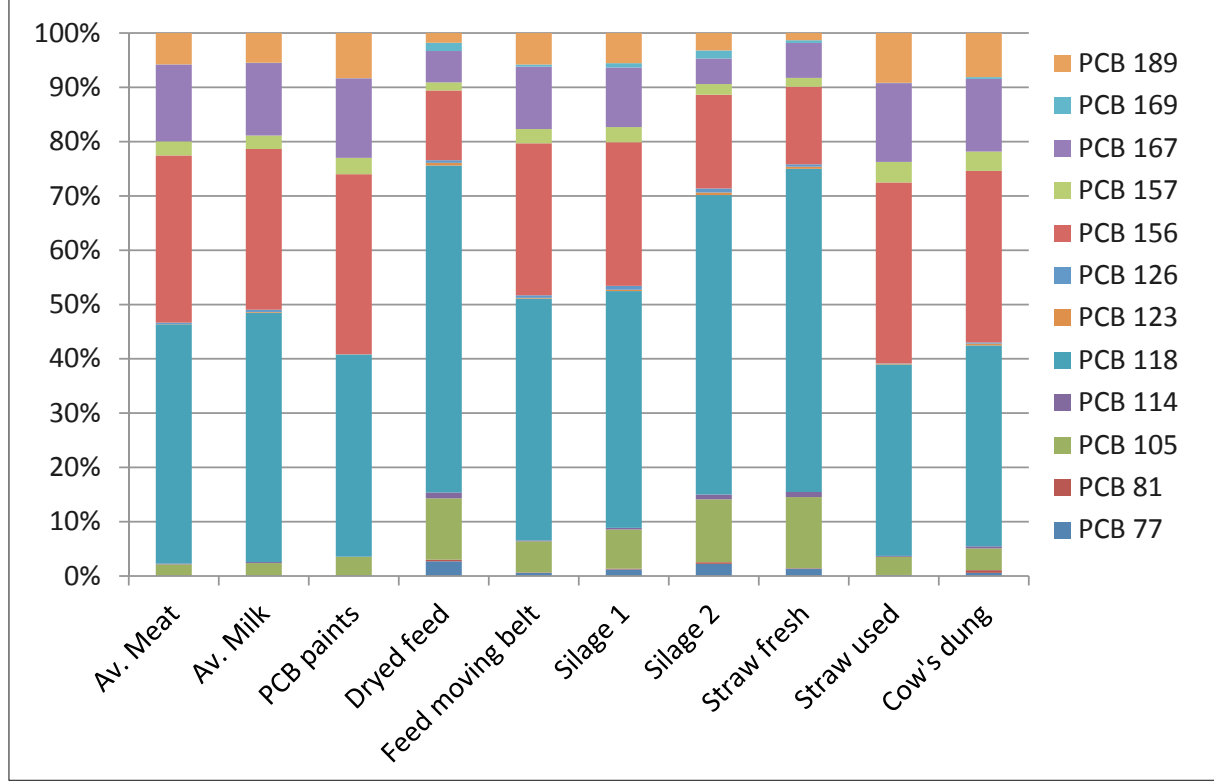

Fig. 2. Comparison of the average (AV) dl-PCB pattern of different samples from farm $C$ with the $\mathrm{PCB}-$ containing wall paints responsible for the high contamination of the stable and the cattle.

vestigations and further activities, finally amounted to around CHF 240,000-. In November 2015, one year after the remedial works took place, mother-cow milk and meat samples from calves (aged 5-6 months) were analysed for PCBs. Happily, a significant average decline of dl-PCBs and ndl-PCBs of $60 \%$ and $63 \%$ respectively in mother-cow milk was observable, going down from $6.0 \mathrm{pg}$ WHO-TEQ ${ }_{2005} / \mathrm{g}$ lw to $2.4 \mathrm{pg} \mathrm{WHO}-\mathrm{TEQ}_{2005} / \mathrm{g} \mathrm{lw}$ and from
$130 \mathrm{ng} / \mathrm{g} \mathrm{lw}$ to $49 \mathrm{ng} / \mathrm{g} \mathrm{lw}$ respectively. Additionally, the levels of dl-PCBs and ndl-PCBs in veal declined in parallel by 69 and $68 \%$ respectively from 17 pg WHO$\mathrm{TEQ}_{2005} / \mathrm{g}$ lw to $5.3 \mathrm{pg}$ WHO-TEQ $2005 / \mathrm{g}$ lw and from $480 \mathrm{ng} / \mathrm{g}$ lw to $150 \mathrm{ng} / \mathrm{g} \mathrm{lw}$, respectively. Despite this very positive trend which demonstrated the success of the elaborate and costly remediation work, levels in mother-cow milk and meat were still slightly above the permitted max- imum level (compare with Table 2).[37] Nonetheless it can be expected that the levels in the mother-cow milk, and consequently in the calves' meat, have further declined in the meantime and today reach levels that conform with legislation. Fig. 3 summarizes diagrammatically the different possible causes leading to higher PCB levels in meat in case of the presence of a PCB point source (e.g. farm C), which partially are also applicable in case of an unknown higher diffusive and environmentally based PCB input in meat (e.g. farm A).

Further investigations carried out at farm A did not reveal any PCB point source in the stable or its near surroundings. Investigations of soil samples from the animals' grazing area and silage samples harvested from these fields showed slightly increased PCB levels, albeit clearly below the permissible maximum levels for soil and feed. On average, ten soil samples analysed had dl-PCB levels of $1.0 \mathrm{ng}$ $\mathrm{WHO} \mathrm{TEQ}_{2005} / \mathrm{kg}$ dry weight (dw) and dioxin levels of $4.0 \mathrm{ng}$ WHO-TEQ ${ }_{2005} / \mathrm{kg}$ $\mathrm{dw}$. Some silage samples showed average dl-PCB levels of 0.27 ng WHO-TEQ ${ }_{2005}$ / $\mathrm{kg} \mathrm{dw}$ and ndl-PCB levels of $5.4 \mu \mathrm{g} / \mathrm{kg}$ dw. Nevertheless, it was assumed that an elevated soil intake by cattle via the ingestion of contaminated silage was responsible for the slightly higher PCB levels in the meat. An increased ash content in the analysed silage samples, which indicated contami-

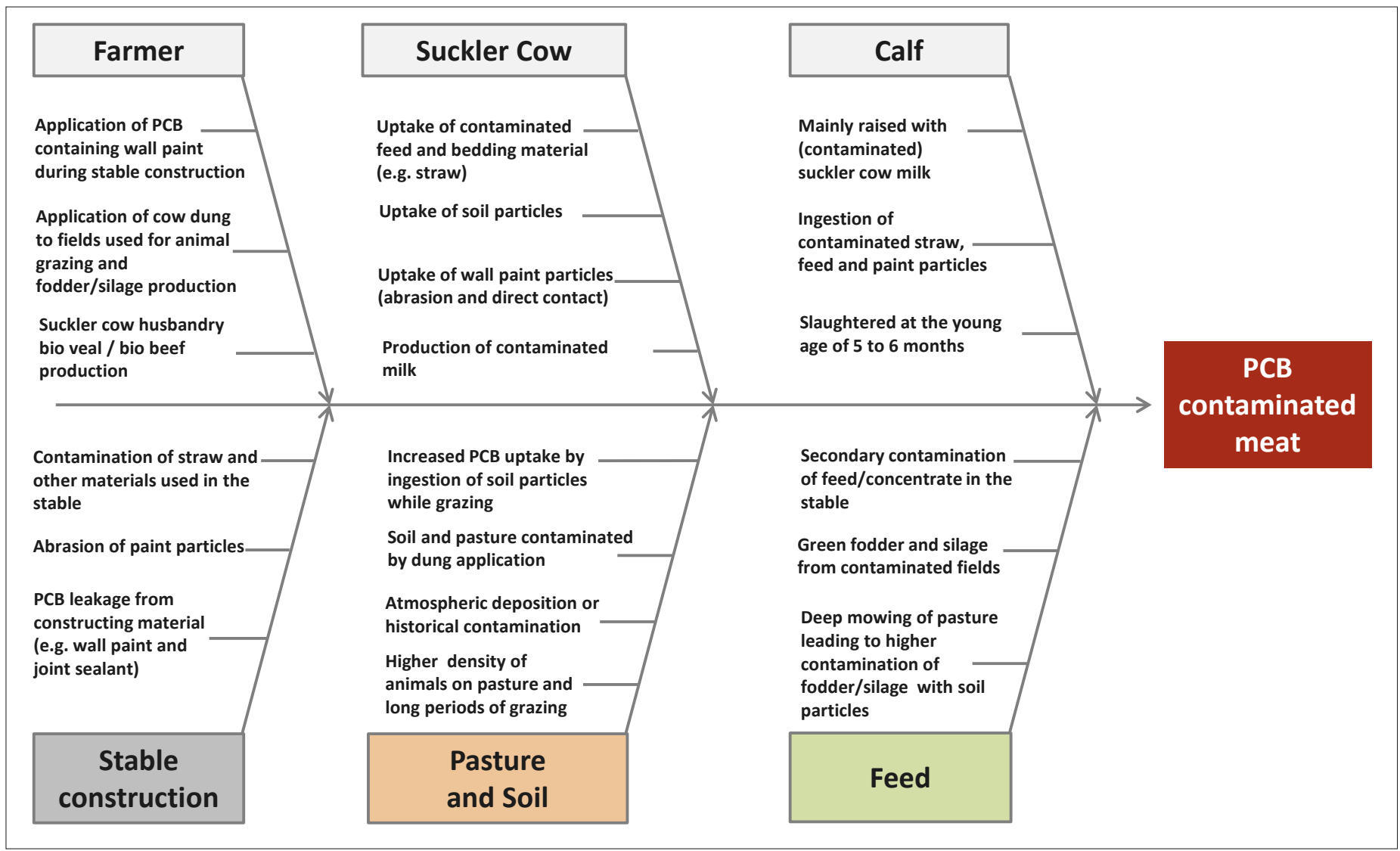

Fig. 3. Cause and effect diagram explaining different PCB input pathways leading to higher PCB levels in meat. 
nation by soil particles was observed, and correlated well with the approximately three times higher PCB levels when compared to other green fodder fed to the animals. It is well known that soil is a major reservoir for POPs and a risk matrix for the transfer of PCBs into cattle, and that a soil uptake of between 3 to $10 \%$ of the mass of green fodder consumed per day is normal. ${ }^{[34,35,38]}$ According to a recently published report by the German Environment Agency (UBA), the daily intake of $2 \mathrm{ng}$ WHO-TEQ ${ }_{2005}$ by a suckler cow via the ingestion of feed could be critical regarding the levels in calves' meat and very probably leads to an exceedance of the ML of $4 \mathrm{pg}$ WHO-TEQ ${ }_{2005} / \mathrm{g}$ lw. ${ }^{[34]} \mathrm{A}$ daily intake of $2 \mathrm{ng}$ WHO-TEQ 2005 would be passed by the ingestion of $12 \mathrm{~kg}$ of feed at $0.15 \mathrm{ng}$ dl-PCB WHO-TEQ ${ }_{2005} / \mathrm{kg} \mathrm{dw}$ and the additional ingestion of $0.36 \mathrm{~kg}$ soil (3\% of the total ingested feed) at $1 \mathrm{ng}$ dl-PCB WHO$\mathrm{TEQ}_{2005} / \mathrm{kg}$ dw (total daily dl-PCB intake of $2.16 \mathrm{ng}$ WHO-TEQ ${ }_{2005}$ ). The intake of $10 \%$ soil with the same amount of feed as mentioned before would equal a daily dlPCB intake of $3.0 \mathrm{ng} \mathrm{WHO}^{-T_{E}}{ }_{2005}$ and clearly pass the critical estimated daily intake of $2 \mathrm{ng}$ WHO-TEQ ${ }_{2005}$. Therefore, the farmer was advised to not set the cutting height of the meadows too short, thus reducing the input of $\mathrm{PCB}$ contaminated soil particles into the green fodder and silage. The application of the recommendations given by the agricultural experts, as well as the alpine grazing of the cattle herd during the summer months, resulted in significantly decreased PCB levels of $50 \%$ in the suckler cows and of $25 \%$ in the calves respectively, as shown by the analyses of blood and meat samples. Meat from ten calves slaughtered at the age of 5 to 11 months was all found to be below the ML of $4.0 \mathrm{pg} \mathrm{WHO}-\mathrm{TEQ}_{2005} / \mathrm{g} \mathrm{lw}$.

\section{Conclusions}

Despite very positive trends regarding the dioxin and PCB levels in our environment, as well as in food and feed, various major contamination incidents during the last two decades clearly highlight the necessity of monitoring programs in this area. Additionally, the uptake of fat-rich food leads to a daily intake of dioxins and PCBs close to or above the tolerable daily or weekly intake recommended by different authorities (e.g. EFSA and SCF). Depending on the age group, significant amounts of the population and overall high-end consumers clearly exceed the TDI/TWI. Meat and meat products alongside dairy products are the main food groups which significantly contribute to the daily uptake of dioxins and PCBs. Therefore, further reductions of the input of these highly toxic and bio-accumulative contaminants into our food must be achieved. The results presented herein, as well as studies from Germany, show that calves from extensive production and suckler cow husbandry, when slaughtered at a young age (5-6 months), tend to have higher dioxin and PCB levels than conventionally bred cattle, which are raised on concentrated feed. Dioxin and PCB levels in concentrated feed are significantly lower when compared to silage and green fodder. The higher PCB intake in the case of extensive rearing is due to an increased basic PCB and dioxin load in the feedstuffs, such as green fodder, and in case of the calves - the suckler cow's milk. In addition, green fodder, which is contaminated with soil particles, leads to an increased absorption of the pollutants in the suckler cow and the calf. While the suckler cow can detoxify herself from dioxins and PCBs by the release of fat-rich milk, the calves accumulate the lipophilic POPs in their body fat and after a few months reach $\mathrm{PCDD} / \mathrm{F}$ and PCB levels close to or above the permitted ML. For this reason, the application of proper agricultural practice is necessary to reduce the contamination of green fodder with soil particles and the contaminants bound therein. Based on the documented case mentioned with the very high PCB contamination via the wall paint, the question arises as to how many farms which were built around the same time also used paints with PCBs as plasticizers. In Switzerland, there are about 40,000 cattle farms. Is the problem perhaps greater than expected? It is not possible to check all the cattle farms and their closer environment for the presence of $\mathrm{PCB}$ point sources, but it should be possible to investigate and estimate, just based on the year of construction (e.g. 1955-1975 when PCBs were mainly used in open applications) how many stables might be at risk. A small but more detailed survey on farms erected during the critical years might reveal if the problem is bigger than expected or not. Additionally, to make farmers aware of the potential risk, their trade association or the Swiss farmers union should inform them via a notice in their trade journal or magazine of the association.

The herein discussed and other investigations showed that even decades after the ban on the use of PCBs, building materials containing this chemical still release PCBs into our environment and contaminate our feed and food. Shall we ever get rid of these persistent organic pollutants? It seems if as dioxins and PCBs are trying to repeat for themselves the famous movie punchline "I'll be back"! It therefore follows on that we must recognise that dioxins and PCBs in meat are still a matter of concern.

\section{Acknowledgments}

I would like to thank the cantonal chemists Silvio Arpagaus (LU) and Matthias Beckmann (GR) for the good collaboration. Additional thanks go to the farmers involved for their kind support. Many thanks go to Julian Bachmann, Esra Ceylan, Melanie Senn and Donatella Perrone for their valuable laboratory assistance. Thanks to Charlotte Driesen for her much appreciated comments. The work was financially supported by the Federal Office for Agriculture (FOAG) and the Federal Food Safety and Veterinary Office (FSVO).

Received: June 5, 2018

[1] A. Hay, Nature 1976, 262, 636

[2] A. Hay, Nature 1976, 263, 538 .

[3] O. Sorg, M. Zennegg, P. Schmid, R. Fedosyuk, R. Valikhnovskyi, O. Gaide, V. Kniazevych, J. H. Saurat, The Lancet 2009, 374, 1179.

[4] M. Zennegg, O. Sorg, P. Schmid, J. H. Saurat, Chimia 2010, 64, 95 .

[5] UNEP, http://chm.pops.int/, accessed July 24, 2017.

[6] UNEP, http://chm.pops.int/TheConvention/ ThePOPs/TheNewPOPs/tabid/2511/Default. aspx, accessed July 24, 2017.

[7] E. Holt, R. Weber, G. Stevenson, C. Gaus, Environ. Sci. Technol. 2010, 44, 5409

[8] K. Breivik, A. Sweetman, J. M. Pacyna, K.C. Jones, Science of the Total Environment 2002, 290, 181.

[9] M. Kohler, J. Tremp, M. Zennegg, C. Seiler, S. Minder-Kohler, M. Beck M. P. Lienemann, L. Wegmann, P. Schmid, Environ. Sci. Technol. 2005, 39, 1967.

[10] P. Schmid, M. Zennegg, P. Holm, C. Pietsch, B Brüschweiler, A. Kuchen, E. Staub, J. Tremp, 'Umwelt-Wissen Nr. 1002', BAFU, Bern, 2010.

[11] M. Zennegg, P. Schmid, J. Tremp, Organohalogen Comp. 2010, 72, 362.

[12] J. Glüge, C. Steinlin, S. Schalles, L. Wegmann, J. Tremp, K. Breivik, K. Hungerbühler, C. Bogdal, PLOS One 2017, 12, e0183768.

[13] P. Schmid, M. Kohler, E. Gujer, M. Zennegg, M. Lanfranchi, Chemosphere 2007, 67, 16.

[14] P. Schmid, E. Gujer, M. Zennegg, C. Studer, Chemosphere 2003, 53, 129.

[15] M. Zennegg, M. Kohler, P. C. Hartmann, M Sturm, E. Gujer, P. Schmid, A. C. Gerecke, N. V. Heeb, H.-P. E. Kohler, W. Giger, Chemosphere 2007, 67, 1754.

[16] C. Bogdal, P. Schmid, M. Kohler, C. E. Müller, S. Iozza, T. D. Bucheli, M. Scheringer, K. Hungerbühler Environ. Sci. Technol. 2008, 42, 6817.

[17] C. Bogdal, P. Schmid, M. Zennegg, F. S Anselmetti, M. Scheringer, K. Hungerbühler, Environ. Sci. Technol. 2009, 43, 8173.

[18] M. Zennegg, M. Muñoz, P. Schmid, A. C. Gerecke, Environ. Int. 2014, 60, 202.

[19] R. Malisch and K. Kotz, Science of the Total Environment 2014, 491, 2

[20] R. Hoogenboom, W. Traag, A. Fernandes, M Rose, Food Control 2015, 50, 670

[21] R. Hites, Environ. Sci. Technol. 2011, 45, 16.

[22] R. Malisch, K. Kypke, A. Kotz, K. Wahl, N. Bitomsky, G. Moy, S. Park, A. Tritscher, S. Y. Lee, K. Magulova, H. Fiedler, Organohalogen Comp. 2010, 72, 1766.

[23] M. van den Berg, K. Kypke, A. Kotz, A Trischer, S. Y. Lee, K. Magulova, H. Fiedler, R. Malisch, Archives of Toxicology 2017, 91, 83.

[24] BLV, https://www.blv.admin.ch/blv/de/home/ lebensmittel-und-ernaehrung/lebensmittelsicherheit/stoffe-im-fokus/dioxine-und-polychlorierte-biphenyle.html, accessed July 25, 2017. 
[25] European Commission - Scientific Committee on Food (SCF), 2001, https://ec.europa.eu food/sites/food/files/safety/docs/sci-com_scf_ out90_en.pdf, accessed July 25, 2017.

[26] US Environmental Protection Agency (US EPA), 2012, https://cfpub.epa.gov/ncea/iris/ iris_documents/documents/supdocs/dioxinv1sup.pdf, accessed July 25, 2017.

[27] M. Schwarz, O. Lindtner, K. Blume, G. Heinemeyer, K. Schneider, Food Add. Contamin. A 2014, 31, 688.

[28] European Food Safety Authority, EFSA J 2012, 10, 2832.

[29] Commission Regulation (EU) 1881/2006 of 19 December 2006
[30] Commission Regulation (EU) 1259/2011 of 2 December 2011 amending Regulation (EC) No 1881/2006.

[31] Commission Recommendation 2013/711/EU of 3 December 2013

[32] Eidgenössisches Departement des Inneren (EDI), Fremd- und Inhaltsstoffverordnung (FIV), 2014, 207.

[33] Eidgenössisches Departement des Inneren (EDI), Kontaminantenverordnung (VHK), 2016, Anhang 5.

[34] R. Weber, UBA Report 2015, https://www. umweltbundesamt.de/en/publikationen/analyse-trendabschaetzung-der-belastung-der-umwelt, accessed July 26, 2017.
[35] R. Weber, M. Albrecht, K. Ballschmitter, J. Berger, E. Bruns-Weller, J. Kamphues, W. Körner, R. Malisch, T. Nöltner, H. Schenkel, K. Severin, C. Vossler, K. Wahl, Organohalogen Comp. 2014, 76, 815.

[36] M. Zennegg, P. Schmid, A. Kuchen, M. Beer, L. Tamborini, M. Beckmann, S. Arpagaus, A. Caduff, M. Lanfranchi, Organohalogen Comp. 2014, 76, 118.

[37] M. Zennegg, M. Beckmann, A. Caduff, M Lanfranchi, Organohalogen Comp. 2016, 78, 503.

[38] G. Rychen, R. Jurjanz, A. Fournier, H. Toussaint, C. Feidt, Environ. Sci. Pollut. Res. 2014, 21, 6440 . 